\title{
Tourism through the Eyes of the Holy See
}

\author{
Zbigniew Dziubiński
}

Josef Pilsudski University of Physical Education in Warsaw, Poland

ABSTRACT

KEYWORDS

\begin{abstract}
The Vatican's vision of tourism is based on Christian humanism, integral humanism and personalism. At the very core of the vision are human beings, who are not only the creators of tourism but also its ultimate goal, and for this reason all values of the natural world should be unconditionally subordinated to the good that are people. Consequently, the fundamental goal of tourism is to satisfy the needs of exploration, relaxation, entertainment and, first and foremost, the spiritual and intellectual needs of every person. Tourism has to help build a sense of community. It should also contribute to the elimination of poverty and foster the sense of responsibility for the environment. Tourism must not be exclusive to the rich and it should never be a time of depravity, promiscuity and, consequently, the degradation of people. Tourism should become an opportunity for all people to discover their contemplative dimension, giving them a chance to see God in nature and first of all, in other people.
\end{abstract}

tourism, Holy See, John Paul II

Contemporary post-modern and post-industrial societies are fascinated by the exploration of the world. It seems we are living in a global village which is the arena of very intensive convergence of world views, systems, values, attitudes and behaviours. On the scale of the entire globe, people enter direct interactions to learn about the heritage of humanity concerning social and symbolic culture and the culture of living (Krawczyk 2007).

The growth of tourism after World War II made it an interesting subject to popes Pius XII, John XXIII and Paul VI and the Vatican started speaking out about the phenomenon on a regular basis. A special place in the formation of the theoretical vision of tourism is held by Pope John Paul II, who looked at the phenomenon of tourism from his characteristic point of view of a priest, theologian, philosopher and ethicist. He focused his attention on the role that tourism could and should play in the process of evangelisation, in the personal development of human beings, in fostering peace and solidarity between communities, in relief for the poor and in raising people's awareness of the necessity to protect the natural world and human culture from degradation.

The line of the Catholic creation of tourism has found a continuator in Pope Benedict XVI, the successor to John Paul II in the Holy See. Like his predecessor, Benedict XVI speaks of tourism as a way to build a better world based on the principles of solidarity and respect for the needs of not only the rich, but also those who hope the tourist industry can help them satisfy their basic existential needs.

The aim of this paper is to present the vision of tourism from the position of the Holy See. 
Consecutive popes create the most representative formal and factual framework of this vision. In this case, we primarily mean the teachings of John Paul II and, to a lesser extent, Benedict XVI. This paper also seeks to show certain characteristic contexts employed in the analysis of the actual and potential values of tourism.

\section{Tourism and its service to humanity}

John Paul II perceives tourism as a chance to improve diverse human potentials, to gather knowledge of the wider world, deepen its spiritual dimension, mould human conscience and aesthetic sensitivity. To the Pope, it is also a chance for physical and healthy development.

By engaging in tourism, people make up for those shortcomings of human existence which are related to contact with others, more profound dialogue and getting to know one another better. "There is no doubt that, when properly oriented, tourism becomes an opportunity for dialogue between cultures and a valuable service to peace (...). Tourism puts us in touch with other ways of living, other religions and other perceptions of the world and its history. This helps people to discover themselves and others, both as individuals and as communities, immersed in the vast history of humanity, heirs to and responsible for a universe that is both familiar and strange. This generates a new vision of others that frees us from the risk of remaining closed in on ourselves" (John Paul II 2001a).

According to John Paul II, a person who travels discovers different places and landscapes, new colours, other forms and ways of perceiving and experiencing nature. Accustomed to one's own home and town, to always the same landscape and familiar voices, the traveller becomes familiar with new images, learns new words and admires the diversity of the world that no one can ever fully grasp. Thanks to this effort, people become more appreciative of what is around them and realise that it all has to be protected. In the Pope's opinion, "Instead of shutting themselves away in their own culture, people today are invited more than ever to open themselves to other cultures and to see themselves in the light of other ways of thinking and living. Tourism is a privileged occasion for this dialogue between civilizations because it sets before the traveller the specific riches that distinguish one civilization from another; because it summons the traveller to remember history and the social, religious and spiritual traditions which history has shaped; and because it favours an ever deepening exchange of riches between people" (John Paul II 2001b).

Individuals and nations get to know one another thanks to cultural exchange. This fosters the growth of societies in the spirit of solidarity and brotherhood. By default, tourists spend time among other people and learn about their living conditions, their problems and their respective religions. Tourism entails solidarity with just pursuits of other nations and it favours conditions under which such pursuits can be recognised in peace.

Tourism helps nurture a sensitivity to other people, it understands "the new imagination of mercy" and builds solidarity, expressed primarily as respect for the dignity of the locals, for their culture and customs, it is manifested in an attitude of dialogue aimed at an integral development of every human being (John Paul II 2003).

The Pope emphasises the advantages of tourism for health and good physical shape. People renew and develop their physical strength through tourism, they toughen their bodies, thus protecting the gift of life. The effort and hardships connected with reaching to the top let one take control over one's shortcomings. Tourists can thus experience the joy of self-control in the sense of controlling all aspects of their humanity (Ostrowski 1997).

"Sport and tourism refer first and foremost to free time, in which activities must be 
encouraged that foster both physical and spiritual development. There are, however, many situations in which tourism and sport are specifically interrelated and condition each other, for instance, when sport actually becomes the main reason for travel at home or abroad" (John Paul II 2004). This refers to large sporting events with athletes and viewers from countries around the world - such as the Olympic Games and football World Cup - as well as less spectacular cases, for example involvement in schools and various sports associations whose participants include children, youth and their parents, for whom physical activity is the fundamental motivation for their travels.

\section{Respect for others as the imperative in tourism}

The Vatican's message for the World Day of Tourism in 2005 made references to the imaginary world of Jules Verne, the humanist, traveller and writer who "intelligently combined fantasy and the scientific knowledge of his time. His voyages, whether real or imaginary, were in fact an invitation to consult the new atlas and a challenge to face responsibly and humanly limits that could no longer be dissembled. At the end of the 19th century, in his incredible journey, Jules Verne crossed the limits imposed by the dominant culture of his time and its vision of the European West as the be-all and end-all" (Sodano 2005).

Although the contemporary world and Europe have removed lots of barriers, even today there are some impediments to access to the benefits of tourism. "New and unheard of possibilities for travel with ever more modern and faster means of transport can make tourism a providential opportunity to share the goods of the earth and of culture. A century after the death of Jules Verne, much of what he imagined has become accessible and has taken a concrete form. The dream of a tourism without borders that could contribute to creating a better future for humanity is coming true" (Sodano 2005).

The tourist industry cannot develop without taking into account the ethical requirements which bind tourism. It is important that those with responsibility for the rise of the tourist industry do their best to promote encounters of people of different nations and cultures.

All those in charge of the tourist sector is called upon to make tourism healthy, popular and accessible to everyone. They should bear in mind that in tourism, the ultimate goal "must always be respect for the human person, in the interests of the common good. Tourists must be motivated by the desire to meet others, respecting their personal, cultural and religious differences; they must be ready for and open to dialogue and understanding, and their behaviour must be respectful, supportive and peace-loving” (Sodano 2005).

This responsibility rests predominantly on Christian communities which in welcoming tourists "must feel committed to offering them the possibility of discovering the riches of Christ incarnate, not only through monuments and religious art works but also in the daily life of a living Church. Moreover, since the beginning of Christianity, journeys have made possible and facilitated the dissemination of the Good News in every corner of the world" (Sodano 2005).

\section{Tourism as a road to evangelisation}

People's numerous travels to less-developed and more remote parts of the world are a good opportunity to evangelise others. This is true about pilgrims and tourists as well as those who deal with tourism as part of their professions and those who live in tourist destinations.

John Paul II notices numerous theological and religious values in tourism. Man is a homo viator. From the theological point of view, any journey is a reflection of a person's inner desire to 
leave this earthly world and reach the ultimate goal. In tourism, people can discover their contemplative dimension by finding traces of God in nature and - first and foremost - in other people (Gałązka 2002). "I firmly hope that tourism will always be an occasion for fruitful encounters: the encounter with God, who shows us his love and his providence in Creation and human achievement; the encounter with oneself, in the silence of reflection and interior listening..." (John Paul II 2000a). The Pope, who frequently speaks about the majesty of his beloved mountains, as well as lakes and rivers, in this way points to the greatness and majesty of God Himself.

To John Paul II, tourism is an opportunity to approach the Creator and become better acquainted with Him. The entire world is filled with signs of God's presence, as the world is His creation and contains His love and goodness. Tourists discover it all in the beauty of nature around them, in historic monuments, achievements of human culture and in encounters with other people.

Magnificent works of human hands, especially sacred buildings and religious art, encourage a more profound spiritual reflection, directing people's thoughts to God. In this way, masterpieces of the surrounding world, through their artistic expression, increase knowledge of religion and stimulate a transfer of truths concerning faith. Faith itself proliferates as well.

Pilgrimages and what is called religious tourism are particularly good opportunities for evangelisation. They create conditions to build and consolidate one's own faith, and to pass it on to fellow pilgrims and to those whom they meet on their route. In the Pope's opinion, pilgrims who give a testimony of faith, good and love in Christ to those they meet, who engage in diverse missionary projects, charities and relief activities - they show the model of evangelic life, consolidate their own faith and influence others by giving an example of Christian conduct (John Paul II 1987).

Tourism may also lead to the heights of holiness, as it did Blessed P. G. Frasatti (Kiera), who whenever he climbed the mountains saw this as another section of his ascetic and spiritual road, a lesson in prayer and adoration, a pursuit of inner discipline and perfection.

\section{The need for pro-environmental tourism}

The Pope also calls for "intelligent tourism" which helps explore the values of the created world and, simultaneously, protects the natural environment from degradation. "We need to learn to gaze at the world through pure and amazed eyes. When this principle is forgotten and they become the tyrants rather than the custodians of nature, sooner or later the latter will rebel" (John Paul II 2000a).

Many of the countless tourists who "tour the world" every year evidently focus in their trips on exploring nature down to its most secret corners. Intelligent tourism makes it possible to add value to the beauty of the created world. Thanks to such tourism, man can approach the world with respect, enjoy it and preserve its equilibrium.

It is an undeniable fact, however, that these days humankind is going through an ecological crisis. Among other things, nature has been devastated by a barbarian model of tourism in which tourist infrastructure is planned and constructed without consideration for its impact on the environment. We must face up to the "profound moral crisis of which the destruction of the environment is only one troubling aspect" (John Paul II 1989).

Still, there is much hope, as many people have been trying to prevent the problem for some time. They first of all seek to restore the spiritual dimension to relations with the world by discovering the original task that God entrusted to humankind (cf. Gn 2: 15). According to the Pope, internal ecology supports external ecology and brings immediate, positive effects, not only in terms of fighting the poverty and hunger of other people, but also in the form of one's personal health and well-being. 
There has been a lot of encouragement for actions to promote fuller development of the culture of life and defeat the culture of death. "We should favour forms of tourism that show greater respect for the environment, greater moderation in their use of natural resources and greater solidarity with local cultures" (John Paul II 2002).

John Paul II calls upon tourists as well as local authorities and communities not to neglect issues concerning the conservation of ecosystems and the riches of biological life in pursuit of economic profit. This necessitates support for actions aimed at combining respect for nature with people's right to use it for their personal development.

Tourism can be an efficient tool in fostering environmental awareness. A less aggressive attitude towards natural environment will help discover and appreciate the goods entrusted to the responsibility of everyone and each person separately. Direct contact with numerous aspects of nature will contribute to a better realisation of the urgent need to take adequate measures to protect nature in order to put a stop to the inconsiderate use of natural resources.

\section{Tourism as a way to eliminate poverty}

Tourism also facilitates solidarity, it encourages internal conversion, reconciliation with brothers and creation of social order based on free will and mercy, justice and peace. It urges us to realise our responsibility for the natural environment and situations of poverty and exploitation that, unfortunately, are the reality for masses of people living in many countries around the world. "Tourism, which has now assumed international dimensions, can thus make a valuable contribution to the culture of solidarity and can foster that international cooperation. Tourism [can be] a primary factor in building a world open to the cooperation of all, through mutual knowledge and direct contact with different realities" (John Paul II 2000b). It can help regions where people live in impoverishment and it can favour elimination of sources of structural injustice.

Tourism should be regarded as a special manifestation of social life whose economic, financial and cultural dimensions crucially influence the lives of individuals and nations. Since tourism is directly linked to people's integral development, it has to be cultivated so as to serve - like other forms of human activity - the growth of civilisation in its most authentic and complete sense, that is, a "civilisation of love" (John Paul II 1987).

Tourism can play an important part in fighting poverty, in the economic aspect as well as social and cultural ones. Through journeys, we become acquainted with different places and situations. This helps us realise the vast gap between rich and poor countries. Tourism provides opportunities to use local resources and give employment to the poorest classes of the population. Travelling and staying away from home are always bound with meeting various people and cultures. Tourists inevitably encounter the painful reality of poverty and hunger everywhere, especially in developing countries. In such situations, tourists should not confine themselves to " islands of happiness," but try to understand the situation of the local community and lead the way with specific acts of solidarity. Therefore, in the Pope's opinion, everything must be done to ensure the well-being of few privileged individuals is not accomplished at the cost of worse living conditions for many others. "One must denounce the existence of economic, financial and social mechanisms which, although they are manipulated by people, often function almost automatically, thus accentuating the situation of wealth for some and poverty for the rest. (...) I warmly hope that tourist activity will always be an effective means of alleviating poverty, of fostering the personal and social growth of individuals and peoples, and of the consolidation of participation and cooperation among nations, cultures and religions" (John Paul II 1987). 


\section{Tourism as a type of "pathological subculture"}

Like a mirror, tourism reflects the contemporary world: increasingly globalised and entangled in a web of universal interdependencies. The development of tourism (culture-related tourism in particular) undoubtedly benefits those who travel and societies which host the visitors. Still, mass tourism frequently produces a kind of sub-culture that humiliates both the tourists and the host communities: it tends to exploit for commercial purposes the traces of "primitive civilizations" and initiation rites that are still practised in some traditional societies. "For the host communities, tourism often becomes an opportunity to sell so-called 'exotic' products: hence the phenomenon of sophisticated holiday resorts that are cut off from any real contact with the culture of the host country or that are characterised by a 'superficial exoticism' offered to the curious who are eager for new sensations. Sadly, this unchecked desire leads at times to humiliating aberrations, such as the exploitation of women and children in an unscrupulous sex trade which is an intolerable scandal. Every possible measure must be taken to ensure that tourism never becomes a latter-day form of exploitation, but is instead a point of fruitful dialogue between different civilizations in which experiences are exchanged in creative ways" (John Paul II 2001b).

Times when the human community undergoes globalisation and when consumerism plays an increasingly important role pose an authentic threat to communities and cultures whose rites and traditions, religious and folk celebrations become superficial in order to meet the expectations of growing numbers of tourists. Local cultures and the people who underlie them undergo transformations and, frequently, degradation. Tourists' needs are satisfied with artificial ethnicity - the opposite of what should be a genuine dialogue between civilisations, a dialogue that respects the authentic and actual identity of everybody. "Indeed the supreme principle that must govern human coexistence is respect for the dignity of each person, created in the image of God and thus a brother or sister to all" (John Paul II 2004). Therefore it is necessary to enable inhabitants of tourist destinations to take part in the planning of tourist activities, so that they can define the economic, ecological and cultural limitations of the latter.

John Paul II points to many other troubling phenomena which are a threat to tourism, such as ostentatiously consumerist tourism, sex tourism, abortion tourism and tourism that degrades nature created by God (John Paul II 2001a). It is thus important that every tourist put appropriate tourism ethics into practice. This makes tourists loyal partners, demanding of themselves and those who coordinate their trips, and makes them partners in the dialogue between civilisations and cultures, which helps build a civilisation of love and peace. Tourism gives people "a providential occasion of deep renewal for believers, a repeated invitation to return to the Gospel sources" (John Paul II 2000b).

\section{More than business}

Tourism is an enormous treasure for contemporary societies. It allows people to become acquainted with the magnificent heritage of other cultures and ethnic communities, a heritage which thus becomes part of the heritage of all people.

Tourism must not focus exclusively on the economic and financial aspects of travelling, although admittedly such issues are certainly important from the point of view of the tourist industry. Still, when limited to the financial dimension, tourism causes a serious disturbance of the global equilibrium. The values of tourism are much greater than just pecuniary profits, because in the first place, tourism enriches humanity through contacts between different civilisations which unveil before one another their cultural, historic, natural, aesthetic, human and spiritual treasures. 
Encounters between members of different cultures and societies allow them to notice the differences in their living conditions. Such situations should prompt impulses of kindness and a sense of overwhelming brotherhood of man. "Travelling, coming into contact with other places and cultures, seems like a new dawn, a richness offered on the face of each brother and sister" (Martino, Marchetto 2006).

\section{REFERENCES:}

Gałązka, G. (2002). Na szczyty z Janem Pawiem II /Climbing to the Summits with John Paul II /. Marki.

John Paul II (1987) Encyclical Sollicitudo rei socialis (on the 20th anniversary of the Populorum progressio encyclical).

John Paul II (1989). Message for the World Day of Peace. L'Osservatore Romano, issue no 12 bis.

John Paul II (2000a). Homily for the Jubilee of Farmers.

John Paul II (2000b). Technology and Nature: Two Challenges for Tourism at the Dawn of the 21st Century. Message of John Paul II for World Day of Tourism. At: http://www.vatican.va

John Paul II (2001a). Tourism: A Means of Peace and Dialogue between Civilizations. Message of John Paul II for the $22^{\text {nd }}$ World Day of Tourism. At: http://www.vatican.va

John Paul II (2001b). God's Footprints in Nature. Contemplation Before "Angelus" in Les Comber. At: http://www.opoka.org.pl

John Paul II (2002). Ecotourism, the Key to Sustainable Development. At: http://www.vatican.va

John Paul II (2003). Turystyka jako narzędzie walki z ubóstwem oraz źródło pracy i ładu społecznego. Orędzie Jana Pawła II na XXIV Światowy Dzień Turystyki. / Tourism as a Tool for Fighting with Poverty and as a Source of Work and the Social Order. Message of John Paul II for the 24th World Day of Tourism / At: http://www. vatican.va

John Paul II (2004). Sport and tourism: two living forces for mutual understanding, culture and the development of societies. Message of John Paul II for the 25th World Day of Tourism. At: http://www.vatican.va

Kiera, S. Sto świec dla Piera Georgia. /A Hundred Candles for Piera Georgia/. At: http://www.opoka.org.pl

Krawczyk, Z. (2007). O turystyce i rekreacji. Studia i szkice./On Tourism and Recreation. Studies and Essays/ Warsaw: WSE.

Martino, R. (card.), Marchetto A. (abp) (2006). Tourism Enriches. Message of the Vatican for World Day of Tourism. At: http://vaticanradio.org

Ostrowski, M. (1997). Turystyka w myśli Jana Pawła II. /Tourism in the Thought of John Paul II/ Peregrinus Cracoviensis, issue no 5 .

Sodano A. (card.) (2005). Travel and transportation: from the imaginary world of Jules Verne to the reality of the 21st century. Message of Cardinal Angelo Sodano in the Holy Father's Name on the Occasion of the 26th World Day of Tourism. At: http://www.opoka.org.pl 